\title{
Community Resilience and the Fulfilment of Child Rights in the Family, School and Community
}

Arijana Mataga Tintor ${ }^{1}$

$\approx$ The present paper presents the experience of researching the resilience of the local community and the fulfilment of the rights of the child. The aim of research was to place the assessment of the rights of the child in the function of local community resilience, focusing on one particular group of rights: the right to participate. This concept is defined through the view of the local community from the perspective of children, parents and teachers, within the context of the realisation of child rights at the local level, which has a direct influence on the development and upbringing of children. The local community selected for study was the town of Velika Gorica in the Republic of Croatia, and the research included qualitative data collected through interviews in seven focus groups. The study included 13 children, 9 parents and 10 teachers. The results show that the key element of children's understanding of the concept of child rights is respect and appreciation from adults despite differences in the amount and type of power possessed by children. The understanding of the concept of child rights from the perspective of adults is based on the need for these rights due to children's dependence, immaturity and need for protection. Discussion about resilience opens up a new dimension for nonprofessional interpretation. The concept of resilience produced ambiguous reactions among children, parents and teachers, being perceived in two ways: as "positive" and "negative". In all three focus groups, participants agree that there is a connection between child rights and resilience. They explain the connection as clear, logical and conditioned by interaction.

Keywords: Resilience; Child rights; Children's participation

1 Grad Velika Gorica, UO za društvene djelatnosti, školstvo i predškolski odgoj, Croatia mladi@gorica.hr 


\section{Odpornost skupnosti ter uresničevanje otrokovih pravic $\mathrm{v}$ družini, šoli in v skupnosti}

Arijana Mataga Tintor

$\propto$ V prispevku sta predstavljena izkušnja raziskovanja odpornosti in virov moči lokalne skupnosti ter doživljanje uresničevanja otrokovih pravic. Cilj raziskave je bil umestitev vrednotenja otrokovih pravic v konceptualni okvir odpornosti. Raziskava je bila osredinjena na pravico otrok do sodelovanja. Koncept je definiran na podlagi doživljanja lokalne skupnosti s perspektive otrok, staršev in učiteljev v kontekstu uresničevanja otrokovih pravic, ki ima neposreden vpliv na otrokov razvoj in vzgojo. V raziskavo je bila vključena skupnost Velika Gorica na Hrvaškem. Podatki za kvalitativno raziskavo so bili zbrani z intervjuji v sedmih fokusnih skupinah. Vključenih je bilo 13 otrok, 9 staršev in 10 učiteljev. Izsledki kažejo, da otroci izpolnjevanje svojih pravic povezujejo predvsem s spoštovanjem s strani odraslih, ne glede na razlike v moči, ki jo otrok poseduje. S perspektive staršev so otrokove pravice potrebne zlasti zaradi njihove odvisnosti, nezrelosti in potrebe po zaščiti. Razprava o odpornosti skupnosti odpira tudi nove poglede v laični interpretaciji koncepta, ki je med otroki, starši in učitelji spodbudil različne odzive. Dojemali so ga na dva načina - kot nekaj "pozitivnega« ali tudi »negativnega«. V vseh treh skupinah (starši, otroci, učitelji) se udeleženci strinjajo, da obstaja povezava med otrokovimi pravicami in odpornostjo oziroma viri skupnosti, pri čemer je povezava odvisna od tipa interakcije.

Ključne besede: odpornost; pravice otrok; sodelovanje otrok 


\section{Introduction to the research problem}

Children are perceived as a social group with a special approach due to their position in society. The UN Convention on the Rights of the Child (2001) is the basic international agreement regulating the rights of children. The Convention clearly obliges states to provide a child care and education system that promotes the child's development and that is accessible to all children equally. The Republic of Croatia signed and ratified the Convention, thus taking on all of the commitments pertaining to it.

Although the fulfilment of child rights has been more serious and effective in the states that signed the Convention, the question of child rights implementation on the local level has not been addressed sufficiently. Two decades after the adoption of the Convention, the time has come to consider this question on the local level, since the first two immediate environments of the child, after the family, are school and the local community.

The study is based on work and research concepts of child rights fulfilment and local community resilience that assume a mutual connection and influence between child rights fulfilment and the building of a healthy and resilient local community. It has the concrete research mission of clarifying the role of child rights in building a resilient community, with a special emphasis on one group of rights: participation rights. Children's participation implies active parental support in expressing their opinions and providing the conditions required for expressing these opinions.

The literature in which a relationship is found between child rights and local community resilience concludes that several possible connections exist with regard to this relationship. The relationship between education and empowerment is based on the initiative of community institutions that educate and invigorate citizens. Connection through social (and even political) activism influences the creation of a positive environment for children to grow up in. Recognition of resilience as an outcome is based on an understanding of healthy child development.

Authors who focus on democracy education and child rights agree that the education of children about their rights and the fulfilment these rights on the part of adults strengthen society because they influence the development of healthy and responsible individuals (Roose \& Bouverne-de Bie, 2007; Thomas, 2007; Tisdall \& Bell, 2006; Williams, 2007). Howe and Covell (2005) state that education on child rights builds up positive mechanisms that encourage positive values in children. Their research data demonstrate the value of teaching children about their rights, as is evident in the acquisition of skills and 
encouragement of the characteristics of democratic leadership and individual responsibility. The authors also reveal the development of personality traits such as self-respect and awareness of individual value, as well as increasing respect for others. The data highlight the importance of democracy education and critical thinking in classrooms.

Torney-Purta et al. (1999, according to Howe \& Covell, 2005) believe that, in addition to families, schools should take more responsibility for civic education. They claim that schools make insufficient efforts to promote child rights, emphasising that learning about these rights must begin with adults. Gurwitch, Pfefferbaum, Montgomery, Klomp, and Reissman (2007) identify resilience elements that influence the building of a resilient local community, namely: connection, commitment and shared values, participation, structure, roles and responsibilities, support and education, critical thinking and skill development, resources and communication. The authors point out that children's resilience can be improved if they participate in family, school, cultural, religious and extracurricular activities. Resilience can be further enhanced if children feel respected and appreciated by others and if they contribute to their community.

Supporters of positive child development focus special attention on interaction between the individual and the environment (Bronfenbrenner, 1986; Chaskin, 2008; Dumont \& Provost, 1999; Fergusson \& Horwood, 2008; Fergus \& Zimmerman, 2005; Fraser, 1997; Rolfe, 2006; Tudge, Mokrova, Hatfield, \& Karnik, 2009). Some authors (Hawkins, Catalano, \& Miller, 1992, according to Bašić, 2009) consider the connection between a young person and the important figures within their community as the key element of the healthy development of young people. There are three protective processes leading to this connection: opportunities for active participation, skills that enable successful participation, and recognition and strengthening of opportunities to use these skills.

The essential meaning of ecological theory (Berger, McBreen, \& Rifkin 1996; Bronfenbrenner, 1986; Fraser, 1997; Ungar, 2011), as well as the theory of risk and resilience (Kirby \& Fraser, 1997; McCarthy, Laing, \& Walker, 2004), is based on respect and fulfilment of human rights, with an emphasis on child rights. In view of the strong need to act on the local level, we may conclude that it is precisely in local communities that the Convention should be implemented, taking into account the specific needs and problems of these communities.

In discussing the relationship between risk and protective factors and community resilience, McCarthy, Laing, and Walker (2004) highlight family and children involvement in making decisions about certain issues regarding life in the community. Parents and children have to know what is happening in the community, and should be given a chance to contribute with their own 
ideas and opinions. Children can be involved on different levels: they can put the information they receive into practice, they can share their attitudes and help by offering a new perspective on a specific situation, and they can be included in decision making by offering their opinion on the types of interventions that may help them.

As a phenomenon, resilience is an active process. Resilient people can successfully manipulate their environment in order to isolate themselves from the negative consequences of harmful events (Luthar \& Ciccheti, 200o; Luthar, Cicchetti, \& Becker, 200o; Masten \& O’Dougherty Wright, 2010; Murray, 2003; Normand, 2007). This makes young resilient people identifiable as those who actively participate in creating their own environment (Scarr \& McCartney, 1983, according to Bašić, 2009). Rutter (1987, according to Bašić, 2009) notes that resilience is a process, not just the identification of static factors, and therefore defines both the process and outcome constructs.

On the other hand, individual and environmental potentials are considered to continuously affect negative risk, stress and trauma factors (Perez et al., 2009, according to Žižak, Ratkajec, Nikolić, Maurović, \& Mirosavljević, 2010). This is very important in terms of treatment, because risk and protective factors operate during the treatment process as well. As a result of their interaction (Ajduković, 200o), resilience (or lack of resilience) is not only a final outcome but also an ever-present potential. Therefore, the concept of resilience, although connected to risk exposure, is focused on strength, not on weakness, and on an understanding of healthy development, or, in other words, on a positive developmental outcome (Luthar, 2006; Masten \& Obradović, 2006; Rutter, 2007; Ungar, 2004; Ungar et al., 2008; Windle, 2011).

Critical school competencies are developed in an environment with an enhanced positive attitude towards critical thinking (McDermott, Scacciaferro, \& Visker, 2012; Vieno, Perkins, Smith, \& Santinello, 2005). The right to participate helps in learning about critical thinking, because by stating one's own opinion other opinions must also be taken into consideration. Different opinions can lead to confrontation and even to conflict, which creates an opportunity for progress in terms of democratic dialogue.

Taking into account and integrating the knowledge and ideas presented thus far, the research was carried out with the aim of understanding concepts of child rights and resilience in the community, family and school environments. The town of Velika Gorica was chosen as a local community in which special, scientifically based programmes for children and youth have been organised over the last 15 years. Some of the features of this town that influence the way of life of children and their families are: its vicinity to the city of Zagreb, 
population growth (about 70,000), an influx of young families, and positive natural increase.

Reviewing, reflecting on and integrating the facts from the relevant scientific literature, and from the rather small quantity of scientific research, enabled the formulation of the present study's work research concept of child rights in connection to child rights awareness (from the perspective of children and important figures who influence their growing up in the community), in connection to the participation right as an essential innovation and challenge for children and adults and for the whole society, and in connection to the estimation of child rights fulfilment from the perspective of children and other community members through changes in education policies and the democratisation of society. The study's research concept of local community resilience is defined in terms of the perception of children, parents and teachers in the context of child rights fulfilment on the local level, where there is a direct influence on child development. In the research, resilience is considered as a capacity to resist and overcome problems and difficulties. This capacity helps to decrease and overcome negative influences despite the presence of risk factors, as well as helping to find positive outcomes and solutions for negative life circumstances. Moreover, local community resilience is considered not only as connected to ways of overcoming crisis situations, but also as a systematically built imperative of the healthy and supportive development and life of its citizens.

Whether these particular outcomes of respecting child rights and building a healthy resilient community are mutually conditioned, and to what extent, is still impossible to conclude on the basis of the available research. This is an ongoing challenge, and part of this challenge has been accepted by the present research.

This study presents research on the connection between child rights fulfilment and some elements of local community resilience. Qualitative data have been used to achieve objectives. The basic aim of acquiring qualitative data was a need and desire for insight into the research problems through a direct approach to the research participants. The research section presents an understanding of concepts of child rights and local community resilience from the perspective of children, parents and teachers.

\section{Research objectives}

The basic objective of the present research is to determine the connection between child rights fulfilment and certain elements of local community resilience. ${ }^{2}$

2 The research is part of a broader research project conducted for the doctoral dissertation "The Realisation of Children's Rights in the Process of Creating a Resilient Local Community”. 
On the basis of literature dealing with children's rights and resilience, the implementation of the Convention on the Rights of the Child is associated with a healthy and resilient environment for children. However, a question arises regarding the participant's attitudes about the process of children's upbringing. According to literature-based expectations, it could be expected that the fulfilment of children's rights in the local community is recognised as an important community capacity.

Some specific aims have been derived from the basic objective:

(1) To gain an insight into how children, parents and teachers understand the concept of child rights.

(2) To gain an insight into how children, parents and teachers understand resilience.

(3) To determine how children, parents and teachers understand the connection between the concepts of child rights and resilience.

\section{Research methodology}

Qualitative data have been used to realise the set objectives. The aim of acquiring qualitative data was to gain insight into the research problems through a direct approach to the research participants.

The main reasons for adopting a qualitative methodology are:

(1) to gain insight into the key research concepts - child rights and resilience from the individual perspective of the child and from the perspective of figures important to the child;

(2) to give a role and importance to the child's right of participation, balanced by the very essence of this right: active involvement according to individual abilities;

(3) to approach the participants with direct communication in order to gain insight into individual perspectives, and to bring the research leader and participants together to work on 'locally relevant facts' pertaining to child rights in terms of new actions in the local community.

Data on the perception of child rights, quality of life and the local community in the town of Velika Gorica were collected through interviews organised in children's, parents' and teachers' focus groups. There were three regular levels of interviews in the groups: introduction, key questions and conclusion questions. Three introduction questions opened the topic of the understanding of child rights and the reasons for special rights. Six key questions were related to resilience and the connection between the phenomenon of resilience and child 
rights fulfilment, quality of life and growing up. Three conclusion questions dealt with perceptions of the relationship between rights, responsibilities and rules.

The qualitative data have been processed according to the principles of qualitative text analysis.

The responses were grouped into categories according to the key concepts and ideas of the research participants. The analysis of data has been made in these categories, and data are integrated and interpreted.

In the qualitative part of the research, 13 children took part in interviews in three focus groups, while 9 parents participated in two focus groups and 10 teachers took part in two further focus groups. The group of children consisted of 7 girls and 6 boys from the 7 th grade. The subsample of parents consisted of 7 mothers and 2 fathers, while the teacher subsample is made up of 10 female teachers. The children's subsample structure is balanced in terms of gender. However, in terms of the important adults, the child rights evaluation is much more coloured with the female point of view, including the author of the present research.

\section{Research results}

\section{How children understand the child rights concept}

The analysed answers show two categories of reasons for the existence of special child rights. The first category is related to power. Children claim that they are weaker, different and powerless, and therefore cannot fight for their rights on their own. The second category, related to respect, conveys a clear message that the need for special child rights lies in the need for child respect despite differences in social power between children and adults.

When asked Do you know what child rights are?, children responded differently. An analysis of the responses enables the recognition of four categories: answers related to concrete child rights, to respect for children and their opinions, to life without violence, and to a decrease in differences and social exclusion.

The concrete rights that children mention relate to their everyday life (their example is that all children have the right to education, which is fulfilled in Velika Gorica because all children go to school). Children associate respect for children with child opinion appreciation ('It is necessary that grown-ups have respect for us and our opinion'). They are dissatisfied with their situation and state that 'it would be better if adults respected us more because children are sometimes smarter than adults'.

Since the participation right is emphasised in the present research, the children were asked What does the participation right mean to you? They 
explain that children have the right to be listened to, to express their opinion, to be involved in making decisions that concern them, and to have their suggestions taken into account. Are you involved in making decisions in your family, school and local community? is the next question, with children providing detailed responses about their experience. The best situation is in their families. They agree on mutual activities and discuss the rules with their parents, and are satisfied with the way their participation right is fulfilled. Next is the local community. Most children perceive the local community (city government, local self-government) as an institution where they have the right to express their opinions, problems and demands. Although they are not completely satisfied with reactions to their needs, they do manage to have their wishes and needs partly fulfilled. On the other hand, children express dissatisfaction concerning schools. Participants of all of the focus groups consider that they have no right to express their opinion in school, and have experienced rejection when their demands had to be supported. Children claim they have no rights in school and are not respected there. They consider the Pupils' Council to be a declarative body with no open possibilities to improve student status. This situation is explained by possible reasons related to school rules, which do not allow any student activities. Almost all activities unrelated to classes (such as school trips, etc.) could be discussed with students, but instead they are agreed upon only among teachers, class teachers and principals. This causes dissatisfaction among students, making them feel inferior and powerless, as some of their statements demonstrate: 'When we say something, it is like we have not said anything, they do not care' 'The worst situation is in school, because no one ever listens to us and we really feel miserable?.

\section{How parents and teachers understand the child rights concept}

The concept of child rights was examined in four adult focus groups: two groups of parents and two of teachers. It is interesting to compare their understanding of child rights.

Parents are highly critical of child rights as a new legal and social phenomenon. Although most parents support the existence of special child rights, some parents consider their existence unnecessary. They justify their opinion by the idea that children and adults should have the same human rights ('Children are the same as adults, aren't they? Consequently, human rights should be valid for them too'). The highest level of criticism is directed towards adults, because they exaggerate with too many different types of documents, including the Convention, on child rights ('With so many rights, child rights are made up in order to hide the fact that there are actually fewer and fewer rights'). However, 
most parents think that child rights have to be specially regulated because children are not independent and do not possess material assets, and therefore need special protection ('Children cannot earn money and are not able to take care of themselves', 'Children are not emotionally and physically mature for independent life'). Some parents state that there are adults who physically, psychologically and existentially threaten children, and there is a need for a system that protects such children. Parents with a highly critical opinion on the existence of special child rights conclude that child rights are inseparable from human rights and therefore discriminatory. ('It is two-faced - children should be treated the same as adults, and adults have made up some special rights for them', 'In the developed world, there are no discussions about it - human rights are the same for all people and children are little people'). These statements initiated a discussion on the concept of child rights, with the parents who believe there is a need for special child rights claiming that children need help in human rights fulfilment because they naturally depend on adults and cannot fight for their rights and interests on their own. Most parents agree that there is a need for special child rights, but think that they should be approached correctly ('These are human rights for the little ones and the weak').

Unlike parents, teachers agree that there must be a special regulation system for child rights and that adults are responsible for their fulfilment ('A child has the right to be cared for by adults'). Like most parents, teachers believe that child rights are necessary due to protection of children whose parents do not take appropriate care of them ('Not all children are in the same situation').

All of the adult participants claim to understand what child rights are and state three groups of basic needs for the existence of child rights: dependence due to objective natural reasons, the immaturity and incompetence of children, and their need for protection. Both parents and teachers know all of the types of rights and can name all of the categories.

The parents' reply to the question What does the participation right mean to you? is that this right enables children to express their opinion, which helps them to be involved in making decisions important to them. According to parents, the right consists of agreement and negotiation between parents and children. Parents decide on the right's fulfilment in the family ('It is a licence for children to participate in decision making'), which is good because adults sometimes do not understand children and should ask them about their opinion ('Adults decide on rules and rights but perhaps do not understand what children think and want'). To sum up, children have the right to express their opinion when parents allow it, with the aim of better understanding their needs and wishes. 
On the other hand, teachers do not have conditions for participation right fulfilment. In their opinion, children can participate in almost all positive aspects of life ('When we respect their participation right we allow children to develop and form their personality').

Regarding the question 'Do children have any influence on making decisions in the family, school and local community?', parents consider that children's influence in the family can even be too great ('Sometimes we even adapt to them too $\mathrm{much}^{\prime}$ ). The main reason for respecting the child's opinion in the family is the desire of parents to make their children happy and satisfied. Even if children do not directly express their desires, they have an indirect effect on the process of fulfilment ('Children have the greatest influence in the family. They influence us directly or indirectly'; 'They are cunning little creatures, they do not have to say anything and we know what we have to do'). Parents generally agree that children's greatest influence on decision making is in the family, directly or indirectly, and that they support this primarily because they want to please their children. Only a small number of parents believe that children can affect decision making in schools ('School sometimes allows them to say what they think and some issues can be changed under their influence'), but most parents disagree with this. They argue that the rules of the school system do not allow students to be involved in decision making ('They do not have any influence in school'; 'The only influential person is the principal'; 'Teachers are all-powerful in classrooms'). According to parents' statements and opinions, it can be concluded that there are two levels of children's influence in schools: the first is declarative, according to which the right of children to be involved in decision making is fulfilled, and the second is real, whereby there are standardised sets of rules that exclude children from making decisions.

Teachers completely disagree with this opinion. Like parents, they think that children have the greatest influence on decision making in families: opportunities for participation exist, and parents respect children's opinion. However, teachers claim that children have a significant influence on decisions made by them as well. As an example, they mention agreement on when to do exams, what to choose for a menu, which plays they want to see and which books they want to read for compulsory reading. Moreover, children vote for classroom representatives to the Pupils' Council, they can evaluate their classmates in oral exams ('Students are much stricter with their classmates and mostly give lower grades than teachers'). In short, the child participation right in schools is fulfilled and children influence teachers' decisions, as the following statement confirms: 'Children participate in school life more than is believed'. 


\section{How children understand the term resilience}

The most confusing question for the participants was: Do you know what resilience is?

The concept of a resilient individual is ambiguous for children: it is perceived both positively and negatively. Children with a negative perception of resilience consider resilient individuals to be lonely and introverted because they are resilient to social rules ('Resilient people are reserved', 'Resilient people do not respect social rules'). In their opinion, resilience, in relation to rules and norms, is not a positive category, as rules represent a social value that is important for a healthy society, and resilience with regard to the rules means disrespecting them ('A resilient person is stubborn and disobedient'). However, most children understand resilience as a positive concept. It was concluded that a resilient person resists negative and harmful influences and has a very strong personality ('A resilient person is one who does not react if someone teases him or her'. 'A resilient person says $N O$ to drugs'). In the opinion of children, there are physical and psychological types of resilience. The physical type means resistance to diseases ('A resilient person is someone who is immune to diseases'), while the psychological type refers to psychological stability ('A resilient person ignores bullies and can talk to a class teacher or principal'). In the end, the positive aspect of resilience prevailed in all of the focus groups, i.e., the view that a resilient individual is someone who can resist negative influences.

The discussion on resilient individuals clarified the term resilience, resulting in the interview concerning a resilient school and a resilient community proceeding without ambiguity with regard to the definition of terms. A resilient school is oriented towards the creation of a positive atmosphere, resistance to harmful and negative behavioural patterns, acceptance of diversity, and respect of child rights. Establishing a positive atmosphere depends on teachers and the dominant school value system accepted by most of the students. Adults working in school are responsible for creating a 'resilient climate' ('In resilient schools, experts help students'). Rather than being 'rejected', students who disrupt this atmosphere are influenced by the majority of their peers, leading to a positive change in their behaviour ('A resilient classroom wins a bad student over', 'A resilient classroom accepts problematic students who cannot harm the class but are improved by the class'). A resilient school accepts all students irrespective of their personality traits, helping them to adapt and create their own resilience ('In a resilient school, students help others with problems on their own. If the situation is serious, then experts help'). It is interesting that children connect a resilient school and child rights already in this set of questions, stating that in a resilient school child rights are respected and fulfilled. 
Children define a resilient local community as a place where resilient individuals live and where schools nurture their own resilience (' $A$ resilient community has resilient people and resilient schools'). Like schools, a community has its own elements of resilience: resistance to harmful influences, a negative attitude towards individuals who behave inappropriately, and the respect and unity of the people who live there ('A resilient community is one where people respect each other and make agreements'). Moreover, children state that a resilient community is a comfortable and safe place to live, in which choices are created and children are offered a range of possibilities for spending their free time.

\section{How parents and teachers understand the term resilience}

Most parents answered the question Do you know what resilience is? by defining the term as a scientific or medical category ('The term resilience reminds me of immunity; if your immune system is strong you can resist diseases'). Some parents define it as a physical term ('Resilience is a physical term meaning resistance to some force'). Only a few parents understand it as a general term on the social level ('It is an ability to resist different influences'). It is interesting that most parents divide resilience into positive and negative aspects. In their opinion, external influences can be both positive and negative, and therefore so can resilience.

In this regard, the participants gave more detailed descriptions when they defined a resilient individual, school and community. If an individual resists positive influences it means that person has negative resilience ('A child has a problem with learning; parents and teachers try very hard but the child does not improve, which means resilience is negative'). Positive resilience implies resistance to negative influences ('That would be a kid who is not influenced by something negative; for example, the kid goes to football matches, supports the team among violent groups but is not with them, does not accept their behaviour'). There is a very significant opinion of a few parents that if resilience is too strong it can be harmful. According to them, there is a need to measure the level of resilience because ('Resilience can be very problematic - my daughter is very resistant in terms of health, her body does not indicate any disease with temperature or anything, and it can have very serious consequences'). More emphasis was placed on this attitude in the discussion about a resilient school ('A resilient school does not allow any external negative influences'). Most parents agree that a resilient school does not necessarily represent something positive. If a resilient school does not allow external influences it means that it cannot face the difficulties and solve the problems that are bound to arise occasionally. It was concluded that school cannot be isolated and resilient to the extent that no problems can reach it. 
In the opinion parents, negative influences create opportunities for learning about different ways to solve problems and deal with stressful situations. As such, resilience could be explained as a flexible term that includes the existence of so-called permeability with regard to real life situations and problems.

There was no detailed discussion of a resilient community, as most parents claimed that whatever is true for school is also true for the community. A resilient community takes care of its inhabitants ('It is a community with politicians who make good decisions'), has a good standard, a favourable environment and many facilities for children and other sensitive social groups. The view regarding limited resilience is valid for the community as well ('It is not good when a community is too resilient because it will be isolated; a person, a school and a community have the right to make mistakes; mistakes teach us something').

Teachers also found a connection between the term resilience and positive and negative context. They explain resilience on the individual level as a medical phenomenon, identifying it with the immunity system ('Resilience is immunity: the condition when a person does not catch an illness'). The longest discussion was about a resilient school. Like parents, teachers assume that a limited amount of negative influence is welcome, as it enables learning about how to react in unexpected and problematic situations. Teachers even claim that in certain cases the education system does not create a quality space for educational possibilities aligned with children's needs. In other words, a resilient school must know how to reduce instructions and influences on a formal level ('A resilient school resists political influences', 'A resilient school conducts its own policies wisely'). Resilient schools influence the building of a resilient community, and resilient communities are like generalised forms of resilient schools ('A resilient community also has its wise politicians and conducts its policies, but on behalf of its citizens').

\section{How children understand the connection between child rights and the concept of resilience}

In all of the focus groups, children agreed that resilience and respecting child rights are connected. This is explained in two ways: a logical connection and a mutual reaction. When children logically connect the terms, they state 'If resilience is good and if rights are good then they belong to a group of good things and share that quality'. The mutual reaction of the concepts is explained by the influence of rights on building resilience and by the reciprocal influence of resilience on respecting rights ('If rights are respected then there is resilience as well', 'but if there is resilience then rights are respected'). These reflections 
encouraged participants to discuss which concept is more important and which has to come first ('It would be perfect if everyone was resilient - children, schools and the community; those who are resilient do not violate others' rights'. 'If people did not violate others' rights it would mean that everyone was resilient'). Students were equally divided when discussing this topic, concluding that the two concepts are strongly connected and that it is meaningless to determine whether rights influence resilience or the other way around ('It is the same as the question about the egg and the chicken').

\section{How parents and teachers understand the connection between child rights and the concept of resilience}

In all of the focus groups, there was a unified opinion regarding a connection between the concepts of resilience and child rights. It is not important which concept was defended, because there is a logical and natural connection between them. Both parents and teachers connect the two concepts in a similar way. Like children, they state that resilience influences the respecting of rights, just as respecting rights builds resilience. Since child rights are regulated, parents think that institutions and community services are responsible for respecting and fulfilling rights ('If child rights are regulated, the resilient community will apply them'). The problem that emerges with regard to child rights and the building of a resilient community is that of the failure to respect existing regulations ('Our state is too standardised, and so is the community'). The large number of set norms prevents their application in practice, which is why parents and teachers consider it necessary to reduce the number of existing norms. Priority should be given to the best norms for the needs of community ('All these norms are traps, because it is impossible to conform to all of them and it is a very bad example for children'). Respecting child rights is extremely important for a good life in the community, and participants claim that the community has to determine its priorities and choose the concept supported by its citizens ('For example, children have the right to play, the community builds parks and playgrounds and sends a message about the importance of child rights').

\section{Discussion and conclusion}

Children's reflections on the concept of child rights provided a good basis for describing their understanding of this legal and psycho-social construct. The key element of their understanding of the concept of child rights is respect and appreciation from adults, despite differences in the amount and type of power they possess. Moreover, the children's concept is of a specific, and 
not abstract, phenomenon. Concretising (concrete thinking is typical of the age group to which the children belong) relates to participation rights, which children discuss primarily through specific rights.

The understanding of the concept of child rights from the perspective of adults is based on the need for these rights due to children's dependence, immaturity and need for protection. Differences in opinion between parents and teachers derive from their positions with regard to children. Teachers tend to be more critical of the parents' role in the fulfilment of child rights, whereas parents criticise the role of schools in this respect.

Children do not perceive the concept of resilience as unambiguous and clear. From their perspective, it is the negative phenomenon of resistance to positive values, while, on the other hand, it is the positive phenomenon of resistance to negative influences. The arguments of the participants who insist on an ambiguous meaning of this concept are not irrelevant. They highlight the importance of clarifying the concept of individual, school and community resilience outside the scientific framework.

Unexpectedly, the concept of resilience produced ambiguous reactions among parents and teachers, being perceived in two ways: both as positive and negative. Moreover, if resilience is too strong, then it is not completely positive. There is a logical basis for the arguments explaining this opinion, as they speak of the need for learning how to react in problematic situations. According to parents, problems and discomforts are part of life, and facing them prepares children for real life, which is never free of difficulties. If children live in a completely resilient environment, they will not be able to learn the skills and methods of dealing with stressful events. This strict definition of resilience supports the fact that it is necessary to clarify terms outside professional circles to avoid literal understanding.

When parents and teachers talk about negative resilience, they identify it with resilience that can go in two directions: as resistance to negative influences and resistance to positive influences. Moreover, for them, resilience is not only an outcome or result, but also a way of life that deals with negative influences.

It can be concluded that discussion about resilience opens up a new dimension for nonprofessional interpretation. Experts can and must integrate complicated mechanisms in one entity, and are therefore obliged to clarify and connect terms within the phenomenon of resilience. However, differences in expert and nonprofessional interpretations can lead to misunderstandings. Nonprofessional interpretation may derive from the semantic origin of the word 'resilience', which is reminiscent of the word 'resistance'. It is important to prevent misunderstanding of the phenomenon of resilience due to semantic ambiguity. 
Burger (1994, according to Ungar, 2008), confirms that there is a reason why some parents and teachers take issue with resilience as an ambiguous concept. In his work 'Risk, Resilience and Protection', he explains the understanding of resilience, mentioning two types of resilience: healthy and unhealthy. Healthy resilience is expressed through pro-social, sympathetic, harmonious and adapted behaviour, as opposed to unhealthy resilience, which manifests itself in aggressive, controlling, introverted or self-destructive behaviour.

Negative resilience is counterproductive. In the short run, such behaviour appears to be a necessary mechanism for facing problems; in the long term, however, it poisons relationships and prevents the development of healthy resilience. By comparing Burger's resilience with that of the participants, it can be concluded that the same two types are identified. Burger's healthy resilience is the positive resilience mentioned by parents and teachers, while unhealthy resilience is the negative resilience. Ungar (2008) warns that there are no empirical proofs for the existence of good and bad resilience, explaining that Burger, along with many others, claim what is obvious intuitively but cannot be confirmed.

Understanding the concept of resilience from the participants' perspective, as well as the clarification of the term resilience, served as an introduction to the realisation of a specific aim: determining and describing how children, parents and teachers understand the connection between the concepts of child rights and resilience.

In all three focus groups, the participants agree that there is a connection between these two concepts. They explain the connection as clear, logical and conditioned by interaction. All of the participants reached a unique agreement, and the results of the discussions can be summed up in three conclusions:

(1) there is a connection between the concepts of resilience and child rights;

(2) the two concepts are reciprocally connected and there is interaction between them;

(3) as a phenomenon related to the individual, the school and the local community, resilience influences respecting child rights, just as the fulfilment of child rights influences building resilience.

Although the literature connects the concept of resilience with concepts of risk and protection factors, and despite the fact that child rights are problematised on general levels (international and national), the idea of the need for the stronger implementation of a system for respecting child rights in local communities has become more frequently expressed lately (Howe \& Covell, 2005; Mortier, 2002; Veerman \& Levine, 2000; Vizek-Vidović \& Žižak, 200o). 


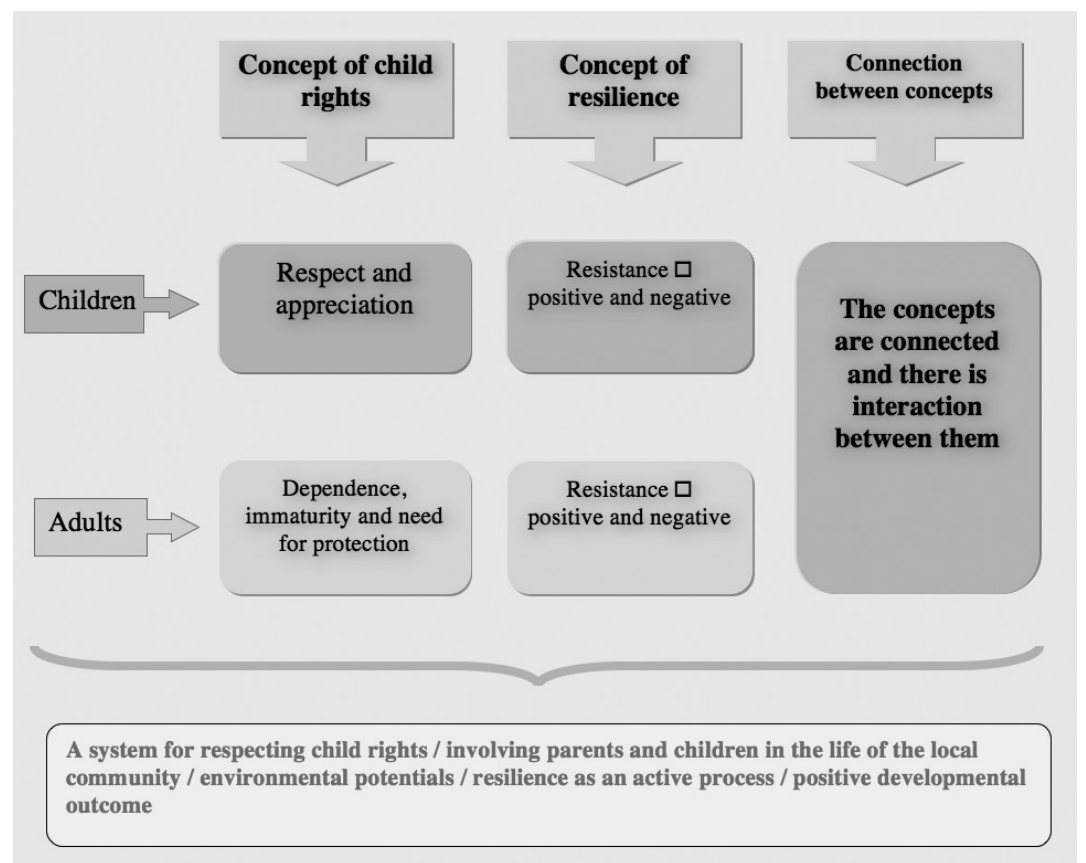

Figure 1. Schematic view of the presented results

If the implementation of child rights fulfilment is connected to the idea of the importance of involving parents and children in the life of the local community, especially in decision making that is important for children and families (McCarthy, Laing, \& Walker, 2004), the result is that local communities become healthier and stronger, and children have a better, safer and happier environment in which to grow up.

In general, the conclusion is that the theoretical contribution of the present research lies in connecting the concepts of child rights and resilience (Figure 1). On the basis of the literature studied, multi-component theoretical models of these concepts have been suggested, both separately and in interaction. Moreover, work research concepts of child rights and community resilience have been constructed. The attempt to determine the understanding of resilience from a nonprofessional perspective is very significant. Differences between nonprofessional and professional perspectives have provoked new and interesting questions regarding the understanding of resilience, as well as regarding mutual understanding in terms of theoretical and practical discourse. On the other hand, on the level of community profit (influence on education policy, the democratisation of society, knowledge of resources, etc.), some elements of these concepts are still to be verified by putting the given results into practice. 


\section{References}

Ajduković, M. (2000). Ecological Multidimensional Approach to the Risk and Protective Factors in the Development of Behavioral Disorders of Children and Youth. In J. Bašić \& J. Janković (Eds.), Risk and Protective Factors in the Development of Behavioral Disorders of Children and Youth (pp. 47-62). Zagreb: Committee for the Prevention of Behavioral Disorders of Children and Youth.

Bašić, J. (2009). Theories of Prevention: Prevention of Behavioral Disorders and Risk Behaviors of Children and Youth. Zagreb: Školska knjiga.

Berger, R. L., McBreen, J., \& Rifkin, M. (1996). Human Behavior: A Perspective for the Helping Profession. New York: Longman Publishers.

Bronfenbrenner, U. (1986). Ecology of the Family as a Context for Human Development: Research Perspectives. Developmental Psychology, 22(6), 723-742).

Chaskin, R. J. (2008). Resilience, Community and Resilient Communities: Conditioning Contexts and Collective Action. Child Care in Practice, 14(1), 65-74.

Dumont, M., \& Provost, M. A. (1999). Resilience in Adolescents, Protective Role of Social Support, Coping Strategies, Self-Esteem and Social Activities on Experience of Stress and Depression. Journal of Youth and Adolescence, 28(3), 343-363.

Fergus, S., \& Zimmerman, M. A. (2005). Adolescent Resilience: A Framework for Understanding Healthy Development in the Face of Risk. Annual Review of Public Health, 26, 399-419.

Fergusson, D. M., \& Horwood, L. J. (2008). Resilience to Childhood Adversity: Results of a 21 -Year Study. In S. S. Luthar (Eds.), Resilience and Vulnerability: Adaptation in the Context of Childhood Adversities (pp. 130-154). Cambridge: Cambridge University Press.

Fraser, M. W. (1997). The Ecology of Childhood: The Multisystems Perspective. In W. M. Fraser (Ed.), Risk and Resilience in Childhood: An Ecological Perspective (pp. 1-9). Washington, DC: NASW Press. Gurwitch, R. H., Pfefferbaum, B., Montgomery, J. M., Klomp, R. W., \& Reissman, D. B. (2007). Building Community Resilience for Children and Families. Oklahoma City: Terrorism and Disaster Center at the University of Oklahoma Health Sciences Center.

Howe, B., \& Covell, C. (2005). Empowering Children: Children's Rights Education as a Pathway to Citizenship. Toronto: University of Toronto.

Kirby, L., \& Fraser, M. (1997). Risk and Resilience in Childhood. In M. Fraser (Ed.), Risk and Resilience in Childhood (pp. 10-33). Washington, DC: NASW Press.

Luthar, S. S. (2006). Resilience in Development: A Synthesis of Research Across Five Decades. In D. Cicchetti \& D. J. Cohen (Eds.), Developmental Psychopathology: Risk, Disorder and Adaptation (pp. 739-795). New York: Wiley. Retrieved January 102013 from http://www.thelearningpartnership.ca/ document.doc? $\mathrm{id}=83$

Luthar, S. S., \& Ciccheti, D. (2000). The Construct of Resilience: Implications for Interventions and Social Policies. Development and Psychopathology, 12(4), 857-885.

Luthar, S. S., Cicchetti, D., \& Becker, B. (200o). The Construct of Resilience: A Critical Evaluation and Guidelines for Future Work. Child Development, 71(3), 543-562. 
Masten, A. S., \& Obradović, J. (2006). Competence and Resilience in Development. Annals of the

New York Academy of Sciences, 1094, 13-27.

Masten, A. S., \& O’Dougherty Wright, M. (2010). Resilience over the Lifespan: Developmental

Perspectives on Resistance, Recovery, and Transformation. In J. W. Reich, A. J. Zautra, \& J. S. Hall

(Eds.), Handbook of Adult Resilience (pp. 213-237). New York: The Guilford Press.

Mataga Tintor, A. (2011). The Realization of the Children's Rights in the Process of Creating Resilient

Local Community. Doctoral Thesis. Zagreb: University of Zagreb, Faculty of Education and

Rehabilitation Sciences.

McCarthy, P., Laing, K., \& Walker, J. (2004). Offenders of the Future? Assessing the Risk of Children and Young People Becoming Involved in Criminal or Antisocial Behaviour. Newcastle: Centre for Family Studies University of Newcastle upon Tyne.

McDermott, J., Scacciaferro, J., Visker, J. D., \& Cox, C. C. (2012). Students' Perceptions of School Learning Climate in a Rural Juvenile Detention Educational Facility. Journal of Juvenile Justice, 1(2), 20-34.

Mortier, F. (2002). We are all Children: Bridges between Rights for Children and Adults. Journal for Juvenile Justice and Children, 3 (extra edition), 10-17.

Murray, C. (2003). Risk Factors, Protective Factors, Vulnerability and Resilience. Remedial \& Special Education, 24(1), 16-27.

Normand, C. (2007). Exploring the Resilience in Youth Living in the High-risk Community.

Doctoral Thesis. Cape Town: Stellenbosch University.

Rolfe, R. E. (2006). Social Cohesion and Community Resilience: A Multi-Disciplinary Review of

Literature for Rural Health Research. Rural Centre, Research Towards Understanding Rural Health in Atlantic Canadian Landscapes. Halifax: Saint Mary’s University.

Roose, R., \& Bouverne-de Bie, M. (2007). Do Children Have Rights or do their Rights have to be Realised? The United Nations Convention on the Rights of the Child as a Frame of Reference for Pedagogical Action. Journal of Philosophy of Education, 41(3), 431-443.

Rutter, M. (2007). Resilience, Competence and Coping. Child Abuse \& Neglect, 31(3), 205-209.

The Convention on the Rights of the Child (2001). Zagreb: The State Office for the Protection of Family, Motherhood and Youth.

Thomas, N. (2007). Towards a Theory of Children's Participation. International Journal of Children's Rights, 15, 199-218.

Tisdall, E. K. M., \& Bell, R. (2006). Included in Governance? Children's Participation in 'Public Decision-Making. In E. K. M. Tisdall, J. Davis, M. Hill, \& A. Prout (Eds.), Children, young people and social inclusion: participation for what? (pp. 105-120). Bristol: Policy Press.

Tudge, J., Mokrova, I., Hatfield,B., \& Karnik, R. (2009). Running head: Bronfenbrenner's theory. Uses and Misuses of Bronfenbrenner's Bioecological Theory of Human Development. Retrieved December 30 2012 from http://www.uncg.edu/hdf/facultystaff/Tudge/Tudge \%20et\%20al\%202009.pdf Ungar, M. (2004). Nuturing Hidden Resilience in Troubled Youth. Toronto: University of Toronto Press. Ungar, M. (2011). The Social Ecology of Resilience. Addressing Contextual and Cultural Ambiguity of a Nascent Construct. American Journal of Orthopsychiatry, 81, 1-17. 
Ungar, M., Liebenberg, L., Boothroyd, R., Kwong, W. M., Lee, T. Y., \& Leblanc, J. (2008). The Study of Youth Resilience across Cultures: Lessons from a Pilot Study of Measurement Development. Research in Human Development, 5, 166-180.

Veerman, P., \& Levine, H. (2000). Implementing Children's Rights on a Local Level: Narrowing the Gap between Geneva and the Grassroots. International Journal of Children's Rights, 8, 373-384. Vieno, A., Perkins, D. D., Smith, T. M., \& Santinello, M. (2005). Democratic School Climate and Sense of Community in School: A Multilevel Analysis. American Journal of Community Psychology, $36(3 / 4), 327-341$.

Vizek-Vidović, V., \& Žižak, A. (2000). Report on the Results of the Survey of Non-governmental Organizations on Projects Related to the Promotion of Children's Rights. Zagreb: Association for Social Policy Initiatives.

Williams, J. (2007). Incorporating Children's Rights: The Divergence in Law and Policy. Legal Studies, $27(2), 261-287$.

Windle, G. (2011). What is Resilience? A Review and Concept Analysis. Reviews in Clinical Gerontology, 21, 152-169.

Žižak, A., Ratkajec, G., Nikolić B., Maurović, I., \& Mirosavljević, A. (2010). Strengths of Children and Youth, Users of Institutional Treatment. Zagreb: University of Zagreb, Faculty of Education and Rehabilitation Sciences.

\section{Biographical note}

Arijana Mataga Tintor was born in Zagreb, Croatia. She is a graduate of the Faculty of Education and Rehabilitation Sciences, University of Zagreb where she received her M.S. (Local Community Key-people in the Prevention of Children and Youth Behavioural Disorders) and Ph.D. (The Realization of the Children's Rights in the Process of Creating Resilient Local Community). She is a member of Steering Committee of Croatian Association of Social Educators. She has worked as a counsellor for children and youth in the city administration of The Town of Velika Gorica in the Department of Social Services and Education. 